\title{
Florida Dairy Farm Situation and Outlook 20061
}

\author{
Russ Giesy, Albert de Vries, Dave Bray and Dan Webb²
}

\section{Situation}

Dairy farming is an important part of Florida's agricultural industry. UF/IFAS projected that the value of cash receipts from the sale of milk in 2004 was $\$ 409$ million, up $19 \%$ from the $\$ 329$ million reported in 2003 by USDA. These cash receipts are approximately $6 \%$ of the total Florida agricultural cash receipts and $29 \%$ of all Florida livestock cash receipts.

The Florida Agricultural Statistics Service has indicated that there were about 135,000 dairy cows in Florida in November, 2005. That is down from 140,000 in November 2003. This decline is consistent with a long term trend showing fewer cows and dairy farms. However, at the same time, total volume of milk produced in Florida increased during 2005 with projections for further growth in 2006.

The Dairy Business Analysis Program (DBAP) is a cooperative effort of the Universities of Florida and Georgia, Southeast Milk Inc., and Southeast Dairy Herd Improvement Association (DHIA). This project annually surveys participating dairy farms about their revenues, expenses, and investments. The dairy farms participating in DBAP 2004 had a wild ride, coming off two consecutive years of challenging milk prices, and then experiencing four hurricanes. Milk prices averaged \$18.98 and peaked over \$21 during summer months. Total revenues averaged $\$ 20.92$ per cwt. (\$3,795 per cow), including milk and cattle sales and other sources of income. Total production costs, including depreciation, averaged $\$ 19.51$ per cwt. These dairy farms had an average of 1,187 dairy cows which produced 18,213 pounds of milk per year. They generated on average over $\$ 4.5$ million in revenues with assets valued at $\$ 7.9$ million. Average net farm income was $\$ 1.41$ per cwt. while return to assets was $7 \%$ and return to equity was $5 \%$.

\section{Outlook}

Florida farm level milk price is determined by nationally determined supply and demand. Most dairy economists predict that in 2006 total U.S. milk production will be up 2-3\% over 2005, based on an expanding U.S. dairy cow herd and continued increases in milk per cow. The strong milk prices of 2004 and 2005 encouraged reduced culling, more assertive feeding, and expansion. Based on that increased production, economists estimate 2006 milk prices to average about $\$ 1$ per cwt. less than 2005 .

The cost of many inputs will likely continue to rise, particularly those affected by increased energy

1. This document is AN160, one of a series of the Department of Animal Sciences, Florida Cooperative Extension Service, Institute of Food and Agricultural Sciences, University of Florida. Published: January 2006. Visit the EDIS Web Site at http://edis.ifas.ufl.edu.

2. Russ Giesy, Extension Agent IV; Albert de Vries, Assistant Professor; Dave Bray, Extension Agent IV; Dan Webb, Professor; Department of Animal Sciences, Cooperative Extension Service, UF/IFAS, Gainesville 32611.

The Institute of Food and Agricultural Sciences (IFAS) is an Equal Opportunity Institution authorized to provide research, educational information and other services only to individuals and institutions that function with non-discrimination with respect to race, creed, color, religion, age, disability, sex, sexual orientation, marital status, national origin, political opinions or affiliations. U.S. Department of Agriculture, Cooperative Extension Service, University of Florida, IFAS, Florida A. \& M. University Cooperative Extension Program, and Boards of County Commissioners Cooperating. Larry Arrington, Dean 
costs; utilities, fuel, fertilizer, hauling, etc.

Additionally, the state of the national economy may cause an increase in interest rates, thus causing concern to those dairy farms that may be building, expanding or adding nutrient handling systems.

\section{Background Information: the Challenge of Dairy Production in Florida}

\section{Production Challenges}

Florida's warm and humid climate is not ideal for dairy cattle that evolved during centuries of selective breeding in the relatively moderate climates of northern Europe. Heat stress has been shown to reduce production by $25 \%$ by reducing feed intake and increasing health problems such as mastitis, lameness and reproductive delay. Mastitis has been estimated to cost producers at least $\$ 300 /$ cow/year. Udder, feet and reproductive health challenges cause the culling of about $35 \%$ of cows each year. This constrains herd replacement dynamics, causing less efficient cows to remain in the herd.

\section{Economic Challenges}

Florida's dairy producers operate under a difficult economic situation. Despite a geographic difference and a product that's difficult to transport, they increasingly compete in a national and international marketplace. Negotiating consistently profitable milk prices has become more difficult for Florida's dairy cooperative because larger handlers from outside the southeast are pushing to gain market share. Ultimately they would like to control a growing market with its high fluid utilization rate and resulting higher price.

Milk price volatility made the dairy farm economic situation in the 1990s and the first half of the century challenging. DBAP data have shown that milk prices ranged from $\$ 15.51$ in 1995 to $\$ 18.98$ in 2004, averaging $\$ 17.41$ from 1995 to 2001 . Price volatility continues to create difficulties for producers because costs of production are much less variable than milk prices. Similarly, DBAP-participating dairy farms averaged $\$ 17.61$ total expense per cwt. from 1995 to 2001 . This is about $25 \%$ higher than a national average.
The size and environment of Florida's dairy farms require large investments, over $\$ 6,000$ per cow. But the return to invested capital is generally insufficient to encourage new investments. The average return on assets ranged from $0 \%$ in 1995 to 9\% in 2001 for DBAP-participating dairy farms. Florida lost a third of its dairy farms in the 1990s.

\section{Environmental Challenges}

Dairy farms face increased regulation due to social environmental pressure. While cows on pasture invoke warm, fuzzy feelings with many Americans, the increasing size of herds causes the public to be concerned with odors, flies and potential losses of nutrients that influence water quality.

The greatest reason for the environmental issues facing Florida dairy producers is the high concentration of animals on farmland. High-producing cows may consume 100 pounds of feed and 50 gallons of water per day. They may excrete 195 pounds of manure and urine. Florida dairy farms average nearly 730 cows and about $50 \%$ of them raise young replacement cattle as well. Thus, there is an extremely high volume of nutrients flowing through the dairy system. Even minuscule percentages of these nutrients, if lost, could command attention of regulatory agencies. Further, if cow densities on land become fixed by regulatory action, these new constraints on herd size will forever limit most farms' opportunity to grow, dooming them to eventual inefficiency and discontinuation.

The cost of nutrient handling systems that will meet the future requirements of environmental regulatory agencies is unknown and perceived to be a major constraint to dairy farms as they commit to the future. These costs have two parts; (a) the original investment costs of engineering and putting the new systems in place and (b) operating and maintaining the systems well into the future. These systems, incorporating significant levels of new technology, have been implemented to ensure that dairy farms efficiently handle nutrients in an environmentally friendly manner. New UF/IFAS research projects are studying the feasibility of using manure nutrients as an energy source in the generation of electricity. The UF/IFAS Extension Service is helping to determine the cost of implementing and operating these new 
systems to aid management decisions for these dairy farms. Also, the information will be valuable to many others that have yet to develop their best responses to environmental regulation.

Size and location differences among dairy farms significantly affect nutrient handling system expense. Additionally, different types of systems have differing initial investment and operating expenses. Dairy farms that employ such new systems take on a competitive disadvantage as investing in these new systems generally does not generate a positive return.

\section{Social Challenges}

The population of Florida continues to grow at a phenomenal rate. This has implications for dairy farms. First, their property is highly valued for development purposes. Second, the demand for milk grows with the population. Third, fluid milk products have limited shelf life, so milk produced in Florida is greatly preferred by processor/handlers. Fourth, higher energy costs have increased the cost of importing milk from distant areas. Lastly, environmental regulatory agencies may become more assertive in 2006 and 2007 with respect to middle and smaller sized dairy farms.

It is recommended that (1) new regulations that may be implemented by environmental agencies be timed coincidentally with opportunities for cost sharing and (2) the state legislature develop an encouragement for new or expanded dairy operations that will meet requirements of concentrated animal feeding operations. Several states, including Texas and South Dakota, have created enticements while states such as Wisconsin have cost shared herd expansion.

\section{Opportunity}

The future for Florida dairying is strong because of the strong market. Florida's growing population ensures a growing demand for fluid milk products which generate the greatest value for dairy farms. Also, high costs of energy help resist transportation of fluid milk into the Florida market from areas with milk surpluses such as the upper midwest and west. There remains a strong future for those dairy farms, ensuring cows a comfortable and safe lifestyle, showing society an environmentally friendly operation while maintaining a profitable business structure in a changing world. 